\title{
Making career decisions in a changing graduate labour market: A hospitality perspective
}

\begin{abstract}
The study seeks to understand how prospective hospitality graduates tackle the career decision-making task. In-depth interviews were conducted with 28 undergraduate hospitality students in the UK. The findings highlight the challenging nature of career decisions within the context of a changing graduate labour market. The adoption of a qualitative method, coupled with career decision-making theory has resulted in a study that gives a voice to the key participants in the education-to-work transition, the students themselves. These insights will enable higher education, policy makers and employers to assist students in their quest for employment.
\end{abstract}

Keywords: Hospitality careers, hospitality students, career decision-making, UK

Article classification: Research paper

\section{Introduction}

Given the increasing focus on employability in higher education (HE) (Knight and Mantz, 2013; Wilton, 2011), in industry (Branine, 2008; Westhead and Matlay, 2005) and in public policy (Department for Business, Innovation and Skills, 2011), we argue an enhanced understanding of hospitality students' career decision-making is timely. However, the factors influencing graduate career decision-making are complex, and the process itself is characterised by unpredictability and instability (Hart and Barratt, 2009; Baruch, 2008). Despite the existence of numerous studies that touch upon hospitality students' career decisions (e.g. Chang and Tse, 2015; Pittaway and Thedham, 2005; Jenkins, 2001; Damonte and Vaden, 1987; Knutson, 1987, 1989; Laker and Gregory, 1989; McCleary and Weaver, 1988), the empirical evidence base lacks depth in terms of how career decisions are in fact made; the vast majority of previous studies having focused on attitudes and preferences. To address this gap, the study explores how hospitality students' career decisions are formed and investigates factors that influence the decision-making process.

Hospitality students are now more concerned about their careers due to the ongoing challenging labour markets, particularly for youth, found in many countries (Choi, Kwon and Kim, 2013). For many students, obtaining a satisfying career is the main reason for pursuing a university degree (Docherty and Fernandez, 2014; Fidgeon, 2010). However, the complexity of the graduate labour market can present a significant challenge for students to negotiate as they find themselves approaching graduation (Docherty and Fernandez, 2014; Green, Hammer and Star, 2009; Connor and Shawn, 2008). Changes in the structure in the composition of graduate labour supply and in the diversity of occupations that graduates subsequently enter upon graduation have necessitated readjustment between $\mathrm{HE}$ and graduate employment (Dredge et al., 2013; Gallagher, 2013; HEFCE, 2012; Wilton, 2011; Hart and Barratt, 2009; Green, Hammer, and Star, 2009; Baruch, 2008). It is upon this backdrop that the study seeks to provide a theoretical foundation that might effectuate a smoother transition from HE to career, an issue that is of continued concern (O'Regan, 2010; Tomlinson, 2007).

Identifying the processes of career decision-making and antecedents of career decisions is key to employers, educators and policy-makers in crafting appropriate employability strategies and facilitating the transition into satisfying employment. It is important to advance our comprehension of this crucial time in graduates' careers. While the study draws on a UK context, in an increasingly globalised world, the changes witnessed in the UK are not unique to it. 
In setting out this study, we initially discuss hospitality careers literature specifically, and then draw upon literature in the field of career decision-making. After explaining the methodological aspects of the study, the findings are presented and evaluated leading to implications for future research and policy-makers alike.

\section{Theoretical Framework}

\subsection{Hospitality students' career decisions}

Although, various studies have explored hospitality students' career decisions (see for example, Jenkins, 2001; Chuang et al. 2007; Richardson, 2009; Kim, McCleary and Kaufman, 2010; Chuang and Dellmann-Jenkins, 2010), it is an area where many questions still remain unanswered. For example, some studies suggest that hospitality students are driven by intrinsic rewards (e.g. interaction with people, nature of the work) (Chuang and DellmannJenkins, 2010), whereas others suggest it is primarily by extrinsic rewards (e.g. pay, career progression) (Kim, McCleary and Kaufman, 2010). However, these studies are in favour of surveys with little space to make sense of hospitality students' perception towards career decision-making. This is important as career decisions represents a significant challenge for students approaching graduation. The graduate labour market is characterised by considerable flux and change as concerns exist about students' ability in making the transition from student to employee (Docherty and Fernandez, 2014; UKCES, 2013).

There is a growing body of literature suggesting the 'graduatisation' of non-traditional jobs, i.e. jobs that were previously typically not held by graduates are now increasingly being filled by graduates (Connor and Shaw, 2008; Walmsley, Thomas and Jameson, 2006). The 'graduatisation' of jobs is what DeFillippi and Arthur (1996) explain as the phenomenon where graduates find employment in areas where financial rewards and qualifications are often to be less than expected. Frequently, non-graduate jobs are being transformed into graduate positions (Connor and Shaw, 2008). This is because the supply of the 'traditional' graduate job (long-term, linear career progression that exists solely in large organisations either as a result of graduate training schemes or by direct entry into functional positions) is far lower than the demand for this type of employment from graduates now entering the labour market (Rowley and Purcell, 2001; King, Pemberton and Burke, 2005). For example, HESA (2012) data show that only $24 \%$ of graduates went into graduate-commensurate hospitality management roles upon graduation.

There is a growing attention on non-traditional graduate employment (Knight and Mantz, 2013; Wilton, 2011; Connor and Shaw, 2008) where considerable importance is attached to small and medium-sized enterprises (SMEs) (Hart and Barratt, 2009; Connor and Shaw, 2008). However, it has been argued that hospitality students tend to hold less favourable attitudes towards SME employment than towards large organisations (Nachmias, Paddison and Mortimer, 2014; Pittaway and Thedham, 2005; Jenkins, 2001). Part of the reluctance is down to graduates' lack of awareness of SME employment opportunities (Belfield, 1999), lack of an attractive salary and long-term career prospects (Nachmias, Paddision and Mortimer, 2014), and students' socialisation towards large organisation employment within their studies (Brown and Hesketh, 2004). In fact, HE plays a critical role in preparing students for entering the 'world of work' (O'Leary and Deegan, 2005; Kroger, 2004). The literature argues that hospitality higher education is heavily weighted towards large graduate recruiters and undervalues SME graduate employment (Doherty et al., 2001).

The general preference for large firm employment, moreover in traditional graduate positions, stands in contrast with the realities of the supply of jobs (Arthur, Khapova and Wilderom, 2005). The UK Destination of Leavers from Higher Education survey, and as reported in the Council for Hospitality Management Education (CHME) report on hospitality management education, found that graduates were more likely to be in a graduate job if they 
were in a SME than if they were employed by a large organisation (Walmsley, 2011). It is therefore quite possible that the hospitality graduate misperceives the nature of many forms of large firm employment, attributing to these the characteristics of graduate training schemes with managerial connotations. Such observation raises questions as to how different factors are important determinants in forming hospitality students' career decisions. Looking at existing studies it appears that little effort has been made to generate insights into the complexity of the career decision-making processes in hospitality. Therefore, understanding this process becomes an important element for this study.

\subsection{Career decision-making process}

We now turn to literature in the area of career decision-making. We need to preface this with the caveat that only a cursory glance can be provided here of what constitutes a vast body of literature going back at least as far as Parson's (1909) guidelines on choosing a vocation. Nonetheless, as many studies of hospitality students' and/or graduates' career decisionmaking are based on attitude or value surveys with otherwise quite limited recourse to the careers literature it is hoped this overview will at least provide for a more theoretically grounded discussion of our data.

Career decision-making can be described as the psychological process in which "one organises information, deliberates among alternatives, and makes a commitment to a course of actions" (Harren, 1977:119). It reflects a cognitive process in which beliefs, perceptions, attitudes and intentions evolve as knowledge and experiences are processed ( $\mathrm{Nabi}$, Holden and Walmsley, 2006). Thus, career decisions are based on the collection and combination of information in a cognitive, bounded and rational process subject to individual preferences (Gati and Asher, 2001).

In this process, an individual's level of self-efficacy beliefs in relation to their career aspirations plays an important role (Mayrhofer et al., 2005; Pounder and Merrill, 2001). Career aspirations measure the strength of an individual's intention and his/her ability to organise, initiate and carry out the course of actions required to achieve personal goals and make career decisions (Lent, Brown and Hackett, 1994). Self-efficacy contributes to the development of career interests (intention to engage in the process), which, in turn, cultivates career decisions and transition actions (Feltz and Payment, 2005) and also strengthens commitment to career choices (Germeijs, Verscheuren and Soenens, 2006). For example, Chuang and DellmannJenkins (2010) research showed that intention to join the hospitality sector is affected by career outcome expectations.

The deliberation involved in making a career decision may lead to confusion, anxiety and indecisiveness (Gati, Krauz and Osipow, 1996). In uncertain labour markets, poor selfawareness, and adaptability has a negative effect on decisional status and commitment to career choices as individuals feel less confident and more ambivalent about their decisions (Gaffner and Hazler, 2002). High levels of self-efficacy, therefore, can lead to successful career transitions (Jung et al., 2004). Nevertheless, employment decisions are bounded by the individual's personal characteristics as they are the object of career actors' strategies. Such boundaries are less permeable for some career actors (Okay-Somerville and Scholarios, 2014) and career decision-making can create feelings of loss of control (Ashforth, 2001). Thus, approach to career decisions becomes an important consideration when exploring the process of career decision-making.

\subsection{Rationality and intuition approaches}

Not all individuals approach the career decision-making process in the same manner. Individuals can base their decisions on rational or intuitive factors "wherein people choose the course of action that is expected to produce desirable consequences" (Greenhaus, Callanan and Godshalk, 2009:164). 
At the one end of the spectrum, individuals make decisions rationally based upon objectively measurable factors such as potential economic benefits and other extrinsic rewards (Turban, 2001). According to Expected Utility Theory, which forms the basis of many approaches to rational decision-making, the total value of an alternative is identified by the multiplication of the value of its components (Brooks and Brown, 2002). Individuals are more likely to join an organisation that is perceived as being the most economically competitive (Boswell et al., 2003). Thus, career opportunities that fail to meet basic economic needs are more likely to be eliminated from consideration (Gati, Krauz and Osipow, 1996). However, the weaknesses of such an approach can result in excessive conservatism, an idealistic nature and an individual understanding of advantages and disadvantages provided by each of the alternatives (Waterman, Waterman and Collard, 1994). According to Osipow (1999) career decisions are not driven primarily by the wishes and desires of the individuals or their own rational approach to the process. Rather it denotes an individual whose career choice is more likely to be influenced by external factors (Agarwala, 2008).

In situations where there are many alternatives, which is likely to be the case in a buoyant labour market, bounded rationality may prevent individuals from fully understanding the manifold advantages and disadvantages resulting from each of the available alternatives. Hence, individuals may use a more intuitive approach to reach a career decision. This is closely associated with 'Satisficing Theory' which argues that individuals usually give preference to 'average' and 'good enough' options in real-life conditions (Gati, Krauz and Osipow, 1996; Howard and Howard, 1997). Decision makers may use various decision approaches to reach a decision by assessing the most important attributes and past experiences (Ballout, 2009; Shiloh, Koren and Zakay, 2001). Gati and Tal (2008) emphasise the gap between the ideal and real-life choices that can be made by individuals. However, the purely intutitive approach to career decision-making has been criticised for its excessive theoretical or speculative nature and its inability to forecast the final choice of an individual (Shavinina, 2003). It is quite problematic to work out a universal intuitive approach because in each particular real situation the limitations will be different.

In both cases, the collection and processing of information as well as the intensity of the information is a key element to decision-making (Athanasou and Van-Esbroeck 2008). As Osipow (1999) indicates, upon approaching the point at which they will be considering their future career, individuals will be subjected to a number of influences and bombarded with a wealth of information, elements of which have an impact upon their career decision-making process. The level of information that is acquired by the student, together with the extent to which they allow external cultural or peer pressure to intervene, all impact upon the robustness and appropriateness of their final career decisions (Greenhaus, Callanan and Godshalk, 2009).

\subsection{Statement of purpose}

Key insights from the review show that career decision-making is highly contingent, individualised and complex, dependent on a range of extrinsic and intrinsic factors. However, the literature on hospitality careers frequently skirts around this issue. Both extrinsic and intrinsic factors describe different sources of influence on career decisions and provide a loose framework for a decision-making process that can be applied to the hospitality context. To date however, even this quite rudimentary distinction has remained largely absent from studies on hospitality students' career decisions.

Using career decision-making literature, the study attempts to explore how hospitality students' career decisions are formed. Graduate labour market and occupational structure changes feed into career decision-making, and should therefore not be dismissed although graduates are faced with a more complicated decision-making scenario as a result. Such uncertainty is likely to influence career aspirations, self-efficacy beliefs and confidence. The 
reviewed literature points to how a student's approach to career decision-making may effect career outcomes. Not only are the factors that influence career decision-making diverse, the process of decision-making itself is not necessarily straightforward, ranging from the purely rational to the purely intuitive. Rational decision-making approaches revolve around procedures for arriving at an optimal decision. Intuitive decision-making approaches take into account people's inability to a) gather all relevant information and b) apply purely cognitive calculations to arrive at an optimal decision based on an individual's preferences. On this basis this study aims to understand the formation of hospitality students' career decisions in the context of a changing graduate labour market.

\section{Research methodology}

The literature on careers has until relatively recently relied heavily on a quantitative approach, itself the result of a positivist stance traditionally adopted by occupational and vocational psychologists. This is explained in some detail by Young and Collin (2004) in the introduction to a special issue on Constructivism in career research in the Journal of Vocational Behavior. In an earlier paper Collin (1998) reviews challenges in the study of career and similarly draws attention to the 'scientific orthodoxy', i.e. positivist world view, from which many prevailing theories of career have developed. Arthur, Hall and Lawrence (1989:8) define career as "the evolving sequence of a person's work experience over time". As such the study of career lends itself to a form of inquiry that places personal experience and the subjective meaning attached to this experience at the forefront of the inquiry. Both in the careers field, but also in tourism (e.g. Walle, 1997; Jamal and Hollinshead, 2001) the legitimacy and value of alternative research paradigms is accepted as they offer different perspectives on what are arguably multifaceted, complex phenomena. Indeed, because of the complexity of graduate career decision-making in hospitality (Wan et al. 2014) it was decided to adopt a qualitative methodology that would aid in providing an individually situated perspective of this phenomenon. In its attempt to pursue embedded, situational understanding this study may be termed interpretive in the Verstehen tradition (Weber, 1949). Furthermore, this study sides with Grant and Perren (2002) who have argued that the real gain in understanding graduate employment will come from detailed, situational and qualitative work and this might be said to be particularly true for hospitality students and graduates where, as argued above, the vast majority of research to date has relied on survey data.

In total, 28 in-depth interviews were conducted with final year undergraduate hospitality management students ( $58 \%$ female and $42 \%$ male students; mean age 22 ) at 5 different universities in the UK (two in the North of England, one in the South East, one in London and one in the West Midlands). The sampling approach was purposive rather than random and was also driven by availability and willingness of participants to participate in the study. The reason for the selection of final year students was the immediacy of career choices to them (compared to students at earlier stages in their programme). The logic and power of a purposive sampling strategy lies in the selection of information-rich cases for in-depth study (Patton, 2002). In our attempt to come to terms with the meaning not the frequency of the social phenomenon (Van Maanen, 1983:9) of career decisions it was felt that a richness of data and saturation of key themes has been achieved. There will always be the potential for the 'new to emerge', as different participants can have diverse opinions (Miles and Huberman, 1994). Nevertheless, additional participants may not shed any further light on the issue under investigation, but they could possibly become repetitive and, eventually, superfluous (Ritchie and Lewis, 2003). New themes stopped emerging after about 15 interviews, and an acceptable interpretative framework was constructed with 28 interviews (the stage of data saturation).

Interviews were conducted at a mutually convenient time and place which usually involved a researcher traveling to the participant's university. Each interview lasted between 60 to 80 minutes. The interviews may be regarded as lightly structured (Wengraf, 2001) in that 
certain key themes as identified in the literature (e.g. separating extrinsic and intrinsic factors) were raised allowing space for the participants to share their own views with only limited input from the researchers. All interviews were recorded digitally and subsequently transcribed and transferred to the qualitative data analysis software Nvivo10.

The analysis of the data was organised on a thematic basis, drawing data from the themes and perspectives that emerged in the data analysis process (Rival, 2004; Patton, 2002). Table 1 illustrates a detailed index of the main themes and subthemes that emerged from the study for subsequent retrieval and exploration (Miles and Huberman, 1994).

\section{Table 1: Data analysis themes}

Key themes served as a 'blueprint' which maps out a logical sequence of datagathering and evaluation as well as providing for a systematic analysis. Miles and Huberman's (1994) tactics for generating meanings and testing relationships between variables throughout the process of analysing the data has been adopted. These tactics were a vital tool to ensure the consistency of the analysis. All participants were fully briefed prior to the interviews in accordance with the lead author's institution's ethical research guidelines.

\section{Findings}

Findings are divided into two parts. Initially the discussion focuses on the formation of participants' career decisions subsequent to which we then discuss how career decisions were intended to be approached upon graduation. We embed quotations from participants to provide them with a voice and illustrate key themes. Arguably, there are a multitude of facets that could be discussed in relation to both of these themes, we draw on the most prominent to emerge from the data.

\subsection{Formation and development of career decisions}

Participants might be described as, prima facie, a group of particularly career-driven individuals. They expressed their determination to develop a career in the future and emphasised the importance of long-term career progression. However, the interviews also show that there was a discrepancy between desire and a plan or strategy to fulfil their career aspirations. It became apparent that participants did not have fully formed career goals resulting in an absence of plans or strategies of how their career aspirations might be achieved $(n=26)$. They described themselves as ambitious and career orientated but without then suggesting any clearly envisaged career goals. It was not as though participants had no goals, as mentioned, but these existed at a very broad level. All participants wanted to have a good career, a good job, but rarely articulated this further:

"I don't really know what is best for me... even if a career is really important for me, I don't know what I am going to do for my career. I want to progress, I want to find a good job, but at this stage I am not sure about my future career prospects".

When participants were asked to explain further their understanding of the labour market composition, findings revealed a less promising picture. Participants expressed a very traditional view of the graduate labour market revolving around (large organisations and management training programmes) $(n=26)$. A preference for traditional careers in large organisations was based on prospective career opportunities, financial rewards and formal training opportunities rather than on the assessment of actual graduate labour market opportunities: 
"I would like to find a place in a graduate programme as I think.... in a structured training programme you can learn an awful lot more... The thing is with big groups as well, generally they have proper training schemes and this is great because you can develop your skills and competence and, of course...become a manager in the shortterm period".

Large organisations are considered to enhance employability as they are regarded as a 'valuable asset' for career progression $(n=19)$. On the whole, large organisations were perceived as an attractive means to develop managerial skills, to work for a reputable, wellknown organisation which would stand participants in good stead for further career development $(n=27)$.

There was very limited consideration of the non-traditional labour market including the small business sector. Few participants commented on SMEs, those that did arguing that they lacked the prestige associated with large firms in the industry. SMEs were also regarded as offering fewer career development and training opportunities and concerns were raised about the lack of formality and formal structures which might thwart career progression:

"Smaller businesses follow their own approach and many times students cannot cope with this approach because they don't get the appropriate training... which is necessary at the beginning of a new job".

\section{And another participant also claimed}

"I'd be restricted within a small company and...if I didn't like it, l'd have to go for another company altogether or another hotel...this will possibly damage my career".

There were however some positive views expressed about SME employment $(n=2)$. It was recognised that in small organisations individuals have the opportunity to get involved more easily in decision-making. One participant argued that by working for a small employer "you learn a lot more because you see a lot of different things and you have to be more flexible...small businesses provide more responsibility, a great sense of authority". However, no further explanation was given as to whether SME employment was regarded as a potential career destination upon graduation.

\subsection{Approach to career decisions}

The findings indicated there was often an overriding factor that dominated the thought process as opposed to a considered weighing up of all relevant information about career opportunities. From an educator's perspective it is perhaps disappointing therefore to note that all participants strongly criticised the lack of information they received about career opportunities in the industry. There was an acknowledgement that most hospitality employers visiting university were large hotel groups and recognised the under-representation of other hospitality businesses. Some participants $(n=4)$ recognised that uneven distribution of information relating to firm size was an issue:

"It is hard to find information about small businesses... it is the hardest thing to find a job and don't forget that people are looking for the easiest way to find a job... large organisations have formal and very attractive recruitment methods where you can easily find information about job opportunities".

Findings revealed that hospitality students' approach to career decisions is likely to be influenced by the higher education experience, the work placement and working conditions. 
For example, lecturers were frequently highlighted as key sources of information on career opportunities and so any biases, whether conscious or unconscious, on the part of university staff will manifest themselves in career decision-making. Some participants $(n=18)$ seem to have recognised this issue as the following excerpt indicates "[...] lecturers promote [a] hospitality careers as an attractive area for opportunities after graduation, but they didn't say anything about the working environment, the diversity of the industry". Further to that, participants complained that they were not adequately prepared for the realities of working life in hospitality prior to their work placement $(n=28)$. For many the placement was revelatory with regard to the reality of working conditions and management practices in hospitality $(n=17)$. A lack of training, recognition, unsocial working hours, and adherence to standards and procedures were regarded negatively with negative implications for the intention to seek hospitality employment $(n=17)$. "Working in the industry is very ruthless... the way managers treat, manage and develop employees in hospitality is not professional. This makes me think whether hospitality is a good industry to work".

The negative image of the industry appears to be a significant factor in influencing career decisions, particularly in terms of moving students away from a hospitality career. The potentially negative affect of the work placement (e.g. Getz, 1994; Kusluvan and Kusluvan, 2000; Barron and Maxwell, 1993) and early work experiences in hospitality (O'Leary and Deegan, 2005) in terms of detracting graduates from hospitality employment has been recognised in a number of studies. Most participants $(n=26)$ argued that they were willing to change industry or a career trajectory in order to progress with their career. "I have to admit that I am looking into other industries as I am not that confident that hospitality is the one for me. I have second thoughts after the placement so I want to make sure that I don't exclude any options". In this regard there was little loyalty to the industry as the vast majority $(n=26)$ highlighted the transferable skills gained on a hospitality degree, which could give them the opportunity to seek employment outside the industry.

\section{Discussion}

In turning to our first research question of how hospitality students' career decisions are formed, it emerged that participants' demonstrated certainty regarding career paths (traditional labour market, large organisation). However, there was a substantial element of uncertainty about their ability to make effective career decisions based in large part on vague career aspirations. There was a strong indication that participants were still very much at an experimental phase of their career decision-making. Perhaps, as participants were reaching the end of their studies, this uncertainty surrounding their career aspirations was at least in part to be expected. Defining career aspirations is a challenging task, especially for young people (Samuel et al., 2001). Nevertheless, the study revealed two distinctive themes: uncertain career aspirations and unrealistic career aspirations. This is a critical point to note as the main elements in the process of decision-making hinge on the extent to which individuals establish realistic career aspirations (Chapman and Webster, 2006).

The anticipated transition into career is characterised by a degree of disillusionment, confusion and uncertainty. This is likely to have an impact on career outcomes as career decisions are affected by the level of self-efficacy and confidence in an individual's ability to organise, initiate and carry out the course of actions required to achieve individual career goals (Mayrhofer et al., 2005; Pounder and Merrill, 2001). It has been recognised that the career decision-making process often involves stress or anxiety, doubts and worries (Feltz and Payment, 2005). This lends further support to the claims of Germeijs, Verscheuren and Soenens (2006) and Lent, Brown and Hackett (1994) that high anxiety and low self-confidence have negative effects upon commitment to career choice, as individuals are more ambivalent about their career decisions. These considerations appear to apply to participants in this study. 
Despite the decline in the significance of the major traditional graduate recruitment destinations, participants still considered more traditional career paths as a typical and attractive route to start their career. This confirms other studies' findings that suggest that most graduates generally prefer employment within large organisations (Hart and Barratt, 2009; Pittaway and Thedham, 2005; Jenkins, 2001). However, this finding creates a dissonance with current trends in the labour market. For many this will still be true but there is a lack of awareness of alternative meanings of career and non-traditional career opportunities. The limited understanding about other aspects of the non-traditional labour market has a direct impact upon their ability to make effective decisions (Hart and Barratt, 2009; Greenhaus, Callanan and Godshalk, 2009).

Focussing on our second research question, i.e. how hospitality students actually approach the career decision-making task, the findings raised concerns about the extent to which participants' are able to make career decisions that adhere to the normative theories of how career decisions should be made, based on a sound understanding of the self, one's abilities and of the current labour market needs. Of course, not all individuals approach career decisions in the same manner (Gati, Krauz and Osipow, 1996) and this was confirmed by our study. Nevertheless, the findings suggested that participants are more likely to apply an intuitive approach of perceiving and responding to decision-making tasks rather than a more rational approach (Athanasou and Van-Esbroeck, 2008). It would be misleading to suggest individuals' career decision-making was random as this was palpably not the case. However, both in terms of the seeking out of relevant information, and the way decisions were then subsequently made points more toward an at times intuitive, at others satisficing approach. On the whole, participants appear to aim to make a good enough decision rather than an optimal decision (Shiloh, Koren and Zakay, 2001).

The overriding impression gained was that our sample of hospitality students made career decisions based on very limited information on available career alternatives. Without sufficient career information, it is difficult to achieve a sense of reality in relation to labour market opportunities. This is because an important stage in the process of career decisionmaking, as Gati, Krauz and Osipow (1996) state, is that individuals are required to become aware of available opportunities in the labour market. If Gati and Tal (2008) are correct in the view that the intensity and amount of information available to the individual has a significant impact on the development of career decision-making process, then the conclusion here is that the career goals of participants in our study will have been limited by a very parochial view of opportunities in hospitality, both in terms of hospitality sub-sectors as well as with regard to careers available in the non-traditional labour market including small businesses. This may function as a constraint on career decision-making.

The findings revealed a loose relationship between participants' expectations, working conditions and employment outcomes. Hospitality students demonstrate limited commitment towards hospitality careers. Their perception had been largely negatively affected by the 'hard knocks syndrome' of working conditions in the industry through their work placement (McMahon and Quinn, 1995) or what Collins (2002) memorably calls the sting of battle.

Furthermore, the higher education experience created a degree of uncertainty about career opportunities in the industry. The creation of unrealistic images of employment in the sector, whether intended or not, are likely to lead to a clash between expectation and actual experience (Ashforth, 2001). Uncertainty about the graduate labour market can have a negative impact upon students' ability to make rational career decisions. 


\section{Conclusion}

The study has sought to provide a perspective on hospitality students' career decision-making that focuses on process rather than solely antecedents or outcomes within the context of a changing graduate labour market. Our data suggest that students hold vague career aspirations and have a poor understanding of the labour market. Limited availability of information in analysing career alternatives suggests that hospitality students make intuitive career decisions upon graduation. If the building blocks of sound decision-making in the form of relevant and accurate information are not present, effective career decision-making will be down to chance. It can be argued that levels of self-efficacy and external factors (higher education practices, work experience and industry working conditions) will affect their ability to organise, initiate and carry out the course of actions required to make effective career decisions.

The urgent message for key stakeholders (policy makers, educators and employers) is to ensure that students have a more accurate understanding of the industry and the nature of the changing graduate labour market. The graduate labour market is the strategic context in which organisations attract suitably skilled candidates needed to achieve their business objectives. In response to this mismatch employers should manage student expectations more effectively by collaborating with $\mathrm{HE}$ institutions in order to help students make improved career choices. This should reduce disillusionment for the students once employed benefitting both the graduate and the employing organisation. Likewise, the exchange of knowledge between the education system and the labour market regarding the qualities (knowledge, skills and competencies) that graduates attain during their university studies and those required in the hospitality industry is essential.

It has become increasingly necessary for universities to pay attention to the skills sustaining the employability of their graduates. It is important for employers and HE institutions to re-consider which graduate skills and competencies can make a difference in their organisations and how best to develop positive links between hospitality students and businesses. In knowledge-based economies where skilled employees are often in short supply (Docherty and Fernandez, 2014), the attraction and retention of graduates is a critical factor in securing the long-term success of the hospitality industry. Therefore, every effort should be made to increase awareness of the non-traditional labour market in a sector that is, after all, heavily skewed towards small businesses.

Finally, it is acknowledged that this study draws on data that relate to 'graduates-tobe' as opposed to graduates themselves. However, the purpose of the study was to explore career decision-making at a point in time where students had not yet completed HE but where the transition to into the labour market was imminent. The study is set within the context of the UK and follows a period of prolonged economic stagnation (although at the time of writing the economic prospects had started to look more favourable). There is also a danger in oversimplifying early careers in hospitality, and specifically the transition from HE into a complex labour market. While the study is UK-based, we argue that similar types of transition difficulties will exist in countries that are experiencing an expanding HE sector coupled with low rates of economic growth, i.e. most of the 'western' world.

With the increased focus on graduate employability a more detailed understanding of how graduates actually make career decisions is timely and we would recommend further research in this area. Further studies in other cultural and labour market contexts might usefully explore similarities and differences compared to the findings here. In a rapidly changing world of work, an improved understanding of the factors and consequences underpinning and resulting from the highlighted developments is critical to students, educators and policy-makers alike. 


\section{References}

Agarwala, T. (2008). Factors influencing career choice of management students in India, Career Development International, 13(4), 362-376.

Arthur, M.B., Hall, D.X., and Lawrence, B.S. (1989). The handbook of career theory. Cambridge: Cambridge University Press.

Arthur, M.B., Khapova, S.N., and Wilderom, C.P.M. (2005). Career success in a boundaryless career world, Journal of Organisational Behaviour, 26(1), 177-202.

Arthur, M.M., and D.M. Rousseau, D. (1996). The Boundaryless Career: A New Employment Principle for a New Organizational Era. Oxford: Oxford University Press.

Ashforth, B. (2001). Role transitions in organisational life: An identity-based perspective. London: Routledge.

Athanasou, J.A., and Van-Esbroeck, R. (2008). International handbook of career guidance. Amsterdam: Springer Science and Business.

Ballout, H. (2009). Career commitment and career success: Moderating role of self-efficacy, Career Development International, 14(7), 655-670.

Barron, P., and Maxwell, G. (1993). Hospitality management students' image of the hospitality industry. International Journal of Contemporary Hospitality Management, 5(5), 5-8.

Baruch, Y. (2008). Managing careers: Theory and practice. London: Prentice Hall.

Belfield, G.R. (1999). The behavior of graduates in the SME labour market: Evidence and perceptions, Small Business Economics, 12(1), 249-259.

Boswell, W.R., Roehling, M.V., LePine, M.A., and Moynihan, L.M. (2003). Individual job-choice decisions and the impact of job attributes and recruitment practices: A longitudinal field study. Human Resource Management, 42(1), 23-37.

Branine, M. (2008). Graduate recruitment and selection in the UK. Career Development International, 13(6), 497-513.

Brooks, L., and Brown D. (2002). Career choice and development. London: John Wiley and Sons.

Brown, P., and Hesketh, A. (2004). The mismanagement of talent: Employability and jobs in the knowledge economy. Oxford: Oxford University Press.

Chang, S., and Tse, E. (2015) Understanding the Initial Career Decisions of Hospitality Graduates in Hong Kong Quantitative and Qualitative Evidence. Journal of Hospitality \& Tourism Research, 39(1), 57-74.

Chapman, D.S., and Webster, J. (2006). Integrating applicant reactions into the critical contact framework of recruiting. International Journal of Human Resource Management, 17(1), 1032-1057.

Choi, Y., Kwon, J., and Kim, W. (2013). Effects of attitudes vs experience of workplace fun on employee behaviors: Focused on Generation $\mathrm{Y}$ in the hospitality industry. International Journal of Contemporary Hospitality Management, 25(3), 410-427.

Chuang, N.K., and Dellmann-Jenkis, M. (2010). Career decision making and intention: A study of hospitality undergraduate students. Journal of Hospitality \& Tourism Research, 34(1), 512-530.

Chuang, N.K., Goh, B.K., Stout, B.L., and Dellmann-Jenkins, M. (2007). Hospitality Undergraduate Students' Career Choices and Factors Influencing Commitment to the Profession. Journal of Hospitality and Tourism Education, 19(4), 28-37.

Collin, A. (1998). New challenges in the study of career. Personnel Review, 27(5), 412-425.

Collins, A.B. (2002). Gateway to the real world, industrial training: dilemmas and problems. Tourism Management, 23(1), 93-96.

Connor, H., and Shaw, S. (2008). Graduate training and development: Current trends and issues. Education and Training, 50(5), 357-365.

Damonte, T., and Vaden, A.G. (1987). Career decisions in hospitality management. Hospitality Education \& Research Journal, 11(2), 51-65.

DeFillippi, R.J., and Arthur, M. (1996). Boundaryless contexts and careers: A competency-based perspective. Journal of Organizational Behaviour, 15(4), 307-324.

Department for Business, Innovation and Skills, (2011). Supporting Graduate Employability: HEI Practice in Other Countries [DBIS]. Retrieved from:

Https://www.gov.uk/government/uploads/system/uploads/attachment data/file/32421/11-913supporting-graduate-employability-other-countries.pdf

Docherty, D., and Fernandez, R. (2014). Career Portfolios and the Labour Market for Graduates and Postgraduates in the UK. Higher Education Funding Council of England. Retrieved from:

http://heer.qaa.ac.uk/SearchForSummaries/Summaries/Pages/HEER000436.aspx 
Dredge, P., Benckendorff, P., Day, M., Gross, M., Walo, M., Weeks, P., and Whitelaw, P. (2013). Drivers of Change in Tourism, Hospitality, and Event Management Education: An Australian Perspective. Journal of Hospitality and Tourism Education, 25(2), 89-102.

Feltz, D.L., and Payment, C.A. (2005). Self-efficacy beliefs related to movement and mobility. Quest, 57(1), 24-36.

Fidgeon, P. (2010). Tourism education and curriculum design: a time for consolidation and review?. Tourism Management, 36(1), 699-723.

Gaffner, D.C., and Hazler, R.J. (2002). Factors related to indecisiveness and career indecision in undecided college students. Journal of College Student Development, 43(1), 317-326.

Gallagher, P. (2013). Graduate transition into work: the bridging role of graduate placement programmes in the small- and medium-sized enterprise workplace. Journal of Education and Work. 1-20.

Gati, I., and Asher, I. (2001). The PIC model for career decision making: Pre-screening, in-depth exploration, and choice. In F. Leong and A. Barak (Eds.), Contemporary models in vocational psychology (pp.7-54). New Jersey: Lawrence Erlbaum Associates.

Gati, I., and Tal, S. (2008). Decision-making models and career guidance. In J. A. Athanasou, and R. VanEsbroeck (Eds.), International handbook of career guidance (pp.157-184). Amsterdam: Springer Science and Business.

Gati, I., Krauz, M. and Osipow, S.H. (1996). A taxonomy of difficulties in career decision making. Journal of Counselling Psychology, 43(1), 510-526.

Germeijs, V., Verschueren, K., and Soenens, B. (2006). Indecisiveness and high school students" career decision-making process: Longitudinal associations and the meditational role of anxiety. Journal of Counselling Psychology, 53(4), 397-410.

Getz, D. (1994). Students' work experiences, perceptions and attitudes towards careers in hospitality and tourism: A longitudinal case study in Spey Valley. International Journal of Hospitality Management, 13(1), 25-37.

Grant, P., and Perren, L.J. (2002). Small business and entrepreneurial research: Metatheories, paradigms and prejudices. International Small Business Journal, 20(2), 185-211.

Green, W., Hammer, S. and Star, S. (2009). Facing up to the challenge: Why is it hard to develop graduate attributes? Higher Education Research and Development, 28(1), 17-29.

Greenhaus, J., Callanan, G., and Godshalk, V. (2009). Career management. London: SAGE Publication.

Harren, V.A. (1979). A model of career decision making for college students. Journal of Vocational Behavior, 14(2), 119-133.

Hart, T., and Barratt, P. (2009). The employment of graduates within small and medium sized firms in England. People, Place and Policy Online, 3(1), 1-15.

Higher Education Funding Council for England - HEFCE, (2012). Supply and demand in higher education. London: Higher Education Funding Council for England.

Higher Education Statistics Agency - HESA, (2012). Statistics - Students and qualifiers at UK HE institutions [British Council]. Retrieved from: http://www.hesa.ac.uk/content/view/1897/239/.

Jamal, T., and Hollinshead, K. (2001). Tourism and the Forbidden Zone: The Underserved Power of Qualitative Enquiry. Tourism Management, 22(1), 63-82.

Jenkins, A.K. (2001). Making a career of it? Hospitality students' future perspectives: An Anglo-Dutch study. International Journal of Contemporary Hospitality Management, 13(1), 13-20.

Jung, T-H., Misko, J., Lee, K., Dawe, S., Yee Hong, S., and Lee, K.C. (2004). Effective measures for schoolto-work transition in the vocational education system: Lessons from Australia and Korea. Australia: National Centre for Vocational Education Research (NCVER).

Kim, B.C., McCleary, K.W., and Kaufman, T. (2010). The new generation in the industry: Hospitality/tourism students' career preferences, sources of influence, and career choice factors. Journal of Hospitality \& Tourism Education, 22(3), 5-11.

King, Z., Pemberton, J., and Burke, B. (2005). The bounded career: An empirical study of human capital, career mobility and employment outcomes in a mediated labour market. Human Relations, 58(8), 981-1007.

Knight, P., and Mantz, Y. (2013). Learning, Curriculum and Employability in Higher Education. London: Taylor and Francis Publications.

Knutson, B.J. (1987). Hospitality Student Survey: Measures of Influences on and Expectations for Post Graduate Employment. Hospitality Education and Research Journal, 11(2), 163-174. 
Knutson, B.J. (1989). Expectations of hospitality juniors and seniors: Wave II. Hospitality Education and Research Journal, 13(3), 193-201.

Kroger, J. (2004). Identity in adolescence: The balance between self and other. Hove: Routledge.

Kusluvan, S. and Kusluvan, Z. (2000). Perceptions and attitudes of undergraduate tourism students towards working in the tourism industry in Turkey. Tourism Management, 21(1), 251-269.

Laker, D.R., and Gregory, S.R. (1989). Attraction and Influence on the Employment Decision of the Recent Hotel and Restaurant Graduate. Hospitality Education and Research Journal, 13(3), 31-42.

Lent, R.W., Brown, S., and Hackett, G. (1994). Toward a unifying social cognitive theory of career and academic interest, choice, and performance. Journal of Vocational Behavior, 45(1), 79-122.

Mayrhofer, W., Steyrer, J., Meyer, M., Strunk, G., Schiffinger, M., and lellatchitch, A. (2005). Graduates' career aspirations and individual characteristics. Human Resource Management Journal, 15(1), 3856.

McCleary, K.W., and Weaver, P.A. (1988). The Job Offer: What today's graduates want. Cornell Hotel and Restaurant Administration Quarterly, 28(4), 28-31.

McMahon, U., and Quinn, U, (1995). Maximizing the hospitality management student work placement experience: A case study. Education and Training, 37(4), 13-17.

Miles, M., and Huberman, A. (1994). Qualitative data analysis. An expanded sourcebook. CA: SAGE Publication.

Nabi, G., Holden, R., and Walmsley, A. (2006). Career-making: Graduating into self-employment. Leeds: National Council for Graduate Entrepreneurship.

Nachmias, S., Paddison, B., and Mortimer, Ch. (2014). Recession: a chance for hospitality SMEs?, Education and Training, 56(5), 414-429.

O’Regan, M. (2010). Graduate transitions to employment: Career motivation, identity and employability. Report, Centre for Career Management Skills. Reading: University of Reading.

Okay-Somerville, B., and Scholarios, D. (2014). Coping with career boundaries and boundary-crossing in the graduate labour market. Career Development International, 19(6), 668-682.

O'Leary, S., and Deegan, J. (2005). Career progression of Irish tourism and hospitality management graduates. International Journal of Contemporary Hospitality Management, 17(5), 421-432.

Osipow, S.H. (1999). Assessing career indecision. Journal of Vocational Behaviour, 55(1), 147-154.

Patton, M. (2002). Qualitative evaluation and research methods. Newbury Park: SAGE Publication.

Pittaway, L., and Thedham, J. (2005). 'Mind the gap': Graduate recruitment in small businesses. International Small Business Journal, 23(403), 403-424.

Pounder, D.G., and Merrill, R. (2001). Job desirability of the high school principalship: A job choice theory perspective. Educational Administration Quarterly, 37(1), 27-57.

Richardson, S. (2009). Undergraduates' perceptions of tourism and hospitality as a career choice. International Journal of Hospitality Management, 28(1), 382-388.

Ritchie, J., and Lewis, J, (2003). Qualitative Research Practice: A guide for social science students and researchers. London: SAGE Publication.

Rival, C. (2004). Coding and analysing data. In C. Seale (Eds.), Researching society and culture (pp. 366392). London: SAGE Publication.

Rowley, G., and Purcell, K. (2001). Up to the job? Graduates' perceptions of the UK Higher Education careers service. Higher Education Quarterly, 55(4), 416-435.

Samuel, H., Osipow, F., Leong, L., and Barak, A. (2001). Contemporary models in vocational psychology. London: Routledge.

Shavinina, L. (2003). The international handbook on innovation. London: Elsevier Publications.

Shiloh, S., Koren, S., and Zakay, D. (2001). Individual differences in compensatory decision-making style and need for closure as correlates of subjective decision complexity and difficulty. Personality and Individual Differences, 30(4), 699-710.

Tomlinson, M. (2007). Graduate employability and student attitudes and orientations to the labour market. Journal of Education and Work, 20(4), 285-304.

Turban, D.B. (2001). Organisational attractiveness as an employer on college campuses: An examination of the applicant population. Journal of Vocational Behaviour, 58(1), 293-312.

UKCES, (2013). Employer Ownership of Skills: Building the Momentum. Wath-upon-Dearne: Commission for Employment and Skills, UK.

Van Maanen, J. (1983). Qualitative Methodology, London: SAGE Publication.

Walle, A.H. (1997). Quantitative versus Qualitative Tourism Research. Annals of Tourism Research, 24(3), 524-536. 
Walmsley, A. (2011). CHME Report on Higher Education Provision. Leeds: Council for Hospitality Management Education.

Walmsley, A., Thomas, R., and Jameson, S. (2006). Surprise and sense making: Undergraduate placement experiences in SMEs. Education and Training, 48(5), 360-372.

Wan, P., King, Y., Wong, A., and Kong, W.H. (2014). Student career prospect and industry commitment: The roles of industry attitude, perceived social status, and salary expectations. Tourism

Management, 40(1), 1-14.

Waterman, R., Waterman, J., and Collard, B. (1994). Toward a career-resilient workforce. Harvard Business Review, 72(4), 87-95.

Weber, M. (1949). The Methodology of the Social Sciences. New York: Free Press.

Wengraf, T. (2001). Qualitative Research Interviewing. Biographic Narrative and Semi-Structured Methods. London: SAGE Publication.

Westhead, P., and Matlay, H. (2005). Graduate employment in SMEs: A longitudinal perspective. Journal of Small Business and Enterprise Development, 12(3), 353-365.

Wilton, N. (2011). Do employability skills really matter in the UK graduate labour market? The case of business and management graduates. Work Employment \& Society, 25(1), 85-100.

Young, R., and Collin, A. (2004). Introduction: constructivism and social constructionism in the career field. Journal of Vocational Behaviour, 64(3), 373-388.

Table 1: Data analysis themes

\begin{tabular}{|l|l|l|}
\hline Themes & Sub-themes & Description \\
\hline $\begin{array}{l}\text { Formation of } \\
\text { career decisions }\end{array}$ & $\begin{array}{l}\text { Career aspirations and } \\
\text { planning }\end{array}$ & $\begin{array}{l}\text { Vague career aspirations; lack of discernible } \\
\text { career plans; focus on career outcomes rather } \\
\text { than on actions. }\end{array}$ \\
\cline { 2 - 3 } & Act of preference & $\begin{array}{l}\text { Poor understanding of the composition and } \\
\text { nature of the labour market. }\end{array}$ \\
\hline \multirow{2}{*}{$\begin{array}{l}\text { Capproach decision } \\
\text { appros }\end{array}$} & Availability of alternatives & $\begin{array}{l}\text { Insufficient career information about available } \\
\text { career alternatives. }\end{array}$ \\
\cline { 2 - 3 } & Higher education experience & Inappropriate career and educational practices. \\
\cline { 2 - 3 } & Work placement & $\begin{array}{l}\text { Disappointment with working practices and } \\
\text { career opportunities; mismatch of expectations } \\
\text { particularly in relation to career progression } \\
\text { and satisfaction. }\end{array}$ \\
\cline { 2 - 3 } & Industry working conditions & $\begin{array}{l}\text { Poor graduate recruitment practices; high rates } \\
\text { of industry exposure. }\end{array}$ \\
\cline { 2 - 3 } &
\end{tabular}

